\title{
The regulatory effects of resveratrol on the expression of renal MMP-2 and MMP-9 in the rat models of diabetes
}

\author{
Erhan BOZKURT ${ }^{{ }^{*}} \odot$, Gökhan PEKTAŞ ${ }^{2} \odot$ \\ ${ }^{1}$ Afyonkarahisar Health Sciences University, Medicine Faculty, Dept. of Int. Medicine, Afyonkarahisar, Turkey \\ ${ }^{2}$ Mugla Sitki Kocman University, Medicine Faculty, Division of Hematology, Muğla, Turkey \\ *ldrerhanbozkurt@gmail.com, ${ }^{2}$ gokhanpektas@gmail.com
}

Received : 04.08.2020

Accepted : 04.09 .2020

Online : :08.09.2020

\section{Resveratrolün sıçan diyabet modellerinde renal MMP-2 ve MMP-9 ekspresyonu üzerindeki düzenleyici etkileri}

\begin{abstract}
Hyperglycemia caused by diabetes mellitus, in sensitive tissues such as the kidney, can cause dysfunction by damaging the blood vessels. Matrix metalloproteinases (MMPs), especially MMP-2 and MMP-9, play a significant role in the degradation of proteins and angiogenesis; while epidermal growth factor receptor (EGFR) is involved in the recovery of damaged tissues. Here in, we investigated the relationship between MMP-2 and MMP-9/EGFR in the kidney tissues of streptozotocin-induced Wistar male rats. We also examined the effects of resveratrol known as a strong tissue-protective on these changes. Diabetes was induced by streptozotocin $(55 \mathrm{mg} / \mathrm{kg})$ and trans-resveratrol $(20 \mathrm{mg} / \mathrm{kg} / \mathrm{day}$ intraperitoneal) was used for treatment. Rats were divided into 4 groups as control, resveratrol (Res), diabetes (Diab) and diabetes plus resveratrol (Diab+Res). Superoxide dismutase (SOD) and catalase (CAT) levels were significantly decreased in the kidneys in the diabetic group, whereas nitrite/nitrate, urea, creatine kinase (CK) and uric acid concentrations increased. MMP-2, MMP-9, calcium-binding protein B (S100B) and platelet-derived growth factor (PDGF) concentrations of kidney were increased although reduced EGFR in the diabetes group. Resveratrol supplementation markedly restored all these structures Diabetes activates MMP related inflammation and oxidative stress by suppressing antioxidant enzymes in the kidney tissues. Resveratrol has partly modulatory effects on diabetes-induced changes.
\end{abstract}

Key words: Diabetes mellitus, resveratrol, kidney, MMP-2, MMP-9

\begin{abstract}
Özet: Diyabetes mellitusun neden olduğu hiperglisemi böbrek gibi hassas dokularda kan damarlarına zarar vererek işlev bozukluğuna neden olabilir. Matriks metaloproteinazlar (MMP'lar), özellikle MMP-2 ve MMP-9, proteinlerin bozunmasında ve anjiyojenezde önemli bir rol oynarken; epidermal büyüme faktörü reseptörü (EGFR) hasarlı dokuların iyileşmesinde rol oynar. Burada streptozotosin ile indüklenmiş Wistar erkek sıçanların böbrek dokularında MMP-2 ve MMP-9/EGFR arasındaki ilişkiyi araştırdık. Ayrıca güçlü doku koruyucu olarak bilinen resveratrolün bu değişiklikler üzerindeki etkilerini inceledik. Diyabet modeli streptozotosin $(55 \mathrm{mg} / \mathrm{kg})$ ile oluşturuldu ve tedavi için trans-resveratrol $(20 \mathrm{mg} / \mathrm{kg} / \mathrm{gün}$ intraperitoneal) kullanıldı. Siçanlar kontrol, resveratrol (Res), diyabet (Diab) ve diyabet + resveratrol (Diab + Res) șeklinde 4 gruba ayrıldı. Diyabet grubundaki sıçanların böbreklerinde superoksit dismutaz (SOD) ve katalaz (CAT) düzeylerinin önemli ölçüde azaldığı buna karşın nitrit/nitrat, üre, kreatinin kinaz (CK) ve ürik asit konsantrasyonlarının arttığı saptanmıştır. Diyabet grubunda renal EGFR düzeyinin azalmasına rağmen MMP-2, MMP-9, kalsiyum bağlayan protein B (S100B) ve trombosit kaynaklı büyüme faktörü (PDGF) düzeyleri artmıştır. Resveratrol takviyesi tüm değişkenleri önemli ölçüde iyileştirdi. Diyabet, böbrek dokularındaki antioksidan enzimleri baskılayarak MMP ile ilişkili inflamasyonu ve oksidatif stresi aktive eder. Resveratrol, diyabetin neden olduğu bu değiş̧iklikler üzerinde kısmen modülatör etkilere sahiptir.
\end{abstract}

Anahtar Kelimeler: Diyabetes mellitus, resveratrol, böbrek, MMP-2, MMP-9

Citation: Bozkurt E, Pektaş G (2020). The regulatory effects of Resveratrol on the expression of renal MMP-2 and MMP-9 in the rat models of diabetes. Anatolian Journal of Botany 4(2): 85-91.

\section{Introduction}

Matrix metalloproteinases (MMPs) are a family of zincdependent proteinases involved in remodeling the extracellular matrix. Some articles have reported that MMPs could play a role in cell apoptosis, angiogenesis, tissue repair and immune response (Ning, 2017). Hyperglycemia and free oxygen reagents increase MMP-2 and MMP-9 levels by inducing MEK/ERK/NfאB pathway and often result in diabetic retinopathy (Renu, 2017; Ankita, 2019). It has been shown in many studies that diabetes-induced hyperglycemia increases the levels of end products Cystatin-C, creatine kinase (CK), urea and uric acid (Adlija, 2006; Talib, 2012; Qian, 2017) by enhancing the levels of oxidative markers such as nitrite/nitrate (Naseer, 2014). Diabetes-induced hyperglycemia also suppresses antioxidant enzymes such as superoxide dismutase (SOD) and catalase (CAT) (Xue-
Wen, 2018). Hyperglycemia is not only limited with increased glucose concentrations, but also it increased advanced glycation end-product concentrations. It increases calcium binding protein B (S100B), a protein of the S-100 protein family. S100B is glial-specific and expressed primarily by astrocytes. S100B delays the elimination of rapidly rising inflammatory markers in traumatic process and tissue damage. It is known to be related to the altered expression of S100B of Alzheimer's disease, melanoma, and type I diabetes mellitus (Guglielmo, 2013). On the other hand, when it comes to renal tissue damage, epidermal growth factor receptor (EGFR) comes into question. EGFR is a tyrosine kinase receptor expressed in the kidney and activated after renal damage (Yoshioka, 1990). This receptor plays a key role in renal electrolyte homeostasis. However, its role in renal pathology is somewhat contradictory since both beneficial and deleterious actions have been found (Melenhorst, 
2008). Accumulating proof indicates a critical relevance of platelet-derived growth factor (PDGF) signaling in renal pathology (Taizo, 2012). A new PDGFR- $\beta$ aiming mouse model has ensured novel insight into the postnatal role of PDGFR- $\beta$ in aging-related glomerular remodeling after nephrectomy (Sigrun, 2004).

Resveratrol, a naturally occurring phytoalexin and polyphenolic compound, which is produced by plants against various infections. It has vasoprotective (Babacanoglu, 2013; Pektas, 2015 and 2018), cardioprotective (Abdelgawad, 2019), anticancer (Abdelgawad, 2019), antioxidant (Akar, 2011; Pektas 2016a, 2017), and anti-inflammatory (Sadi, 2015; Koca, 2016; Pektas, 2016b) properties and it effects some cellular processes like angiogenesis (Pektas, 2017), apoptosis (Pektas, 2016a), proliferation (Pektas, 2016a), as well as oxygen radical formation (Akar, 2011). In a recent study, resveratrol has been shown to be effective in the treatment of endometriosis by increasing MMP-2 and MMP-9 levels (Mahshad, 2019). In another study, it has been shown that decreased EGFR levels by $\mathrm{CdCl} 2$ in the testis of mice were normalized with resveratrol supplementation (Sreyashi, 2016).

The investigation of streptozotocin (STZ)-induced diabetes on kidney tissue MMPs/EGFR and oxidative process and their modification by resveratrol will provide new insights to understand the mechanisms. Therefore, here in, we investigated the effects of STZ-induced diabetes and resveratrol supplementation on the protein levels of MMP-2/MMP-9/EGFR and oxidant/antioxidant structures in kidney tissue of rats. We hypothesized that chronic administration of supplemental resveratrol would prevent diabetic renal damage by the restoration of MMPs/EGFR and decreasing oxidative stress.

\section{Materials and Method}

\subsection{Chemicals}

Trans-resveratrol was purchased from Molekula (Gillingham, Dorset, UK) and STZ was obtained from Sigma (St. Louis, MO, USA). The purity of resveratrol was tested by HPLC followed with LC-MS and $98 \%$ of the constituent was determined as trans-resveratrol. All other chemicals used in this study were of the highest analytical grade available.

\subsection{Animals and treatment procedure}

All protocols for animal usage were approved by the Ethical Animal Research Committee of Afyon Kocatepe University (AKUHADYEK-2019/49533702-91). Experiments were performed on 8-week-old adult male Wistar rats weighing between 300-350 g. They were maintained under temperature-controlled conditions (20$22^{\circ} \mathrm{C}$ ) with a 12 -h light-dark cycle and fed with standard rodent diet: $62 \%$ starch, $23 \%$ protein, $4 \%$ fat, $7 \%$ cellulose, standard vitamins and salt mixture (chow pellet). After 1 week, the rats were randomly separated into 4 groups. The control group included 12 rats that were injected only with vehicle, $10 \%$ dimethyl sulfoxide (DMSO), for 4 weeks. The resveratrol group (12 rats) was administered a daily dose of $20 \mathrm{mg} / \mathrm{kg}$ resveratrol in vehicle intraperitoneally (i.p.) throughout the 4-week period. The diabetes group (12 rats) received a single i.p. dose of STZ $(55 \mathrm{mg} / \mathrm{kg}$ ) dissolved in $0.05 \mathrm{M}$ citrate buffer $(\mathrm{pH} 4.5)$ and daily injections of vehicle for 4 weeks. The diabetes+resveratrol group contained 9 rats that received a daily dose of $20 \mathrm{mg} / \mathrm{kg}$ resveratrol i.p. throughout the 4week period, starting from day 2 after STZ administration. Blood glucose concentrations from the blood of the tail veins were determined weekly using Accu-Check Go (Roche, Germany) glucometer. A blood glucose concentration higher than $200 \mathrm{mg} / \mathrm{dL}$ served as the criteria for diabetes. At the end of the study period, all rats were decapitated and the kidney tissues were blotted dry, frozen in liquid nitrogen, and stored at $-85^{\circ} \mathrm{C}$ for further use.

\subsection{Measurement of metabolic parameters in the renal tissue}

Kidney samples were homogenized in $0.1 \mathrm{M}$ phosphate buffer 1:10 (w/v), pH 7.4, and 24000 cycles/min (Ultra Turrax, IKA Works Inc., USA), and ultrasonicated at 20000 cycles/s for $1 \mathrm{~min}$ (Dr. Hielscher, Germany). Homogenates were centrifuged at $10000 \mathrm{x} \mathrm{g}$ and $4{ }^{\circ} \mathrm{C}$ for $15 \mathrm{~min}$, and the supernatants were collected. All the samples were stored at $-85^{\circ} \mathrm{C}$ until analysis. Renal glucose, triglyceride, total cholesterol (Spinreact, Santa Coloma, Spain), CK, urea, and uric acid (Biolabo, France) levels, were determined by standard enzymatic techniques. Renal nitrite/nitrate, $\mathrm{Cu} / \mathrm{Zn} \mathrm{SOD}$, and CAT levels were measured using assay kits (Cayman Chemical, USA).

\subsection{Measurement of renal MMP-2, MMP-9, EGFR, S100B, PDGF, and Cystatin-C}

Total protein contents were determined using the Lowry method (Lowry, 1951). The levels of renal MMP-2, MMP-9, EGFR, S100B, PDGF, and Cystatin-C concentrations were measured using commercially available rat-specific ELISA kits (eBioscience, Bender Med. Systems GmbH, Vienna, Austria) according to the manufacturer's protocols.

\subsection{Statistical analysis}

The results are given as mean \pm standard error of the mean (SEM); $\mathrm{n}$ is the number of rats. Statistical analyses were performed by Student's t-test for unpaired data or one-way ANOVA followed by the Bonferroni post hoc analysis where appropriate by using Prism 5.02 GraphPad software. Values were considered to be significantly different when the p-value was less than 0.05 .

\section{Results}

3.1. Effects of resveratrol on body weights and the renal metabolic characteristics of the rats

The body weights in the diabetes group were significantly lower than those of control rats and unchanged after resveratrol supplementation (Table 1). STZ-induced diabetes increased renal glucose, triglyceride, and total cholesterol contents when compared to the control group. Resveratrol supplementation partially restored these abnormalities in rats with diabetes (Table 1). Renal levels of CK, urea, and uric acid, which are the indicators of renal damage, were increased with STZ-induced diabetes. Resveratrol administration normalized renal CK and uric acid levels but did not change urea levels (Fig. 1B, 1C, 1D). A similar marker called cystatin-C did not change in all groups (Fig. 1A). 
3.2. The effects of resveratrol on MMPs, EGFR, S100B, PDGF and the other markers in the kidney tissues

MMPs (MMP-2 and MMP-9), which are key enzymes for destructive extracellular matrix, were dramatically increased in the kidney of rats with STZ-induced diabetes. Resveratrol supplementation to rats with diabetes significantly suppressed expression levels of these enzymes (Fig. 2A, 2B). EGFR which has antiinflammatory, anti-apoptotic, neurotrophic, and neuroprotective effects, was reduced in the diabetes group compared to control. Resveratrol showed restorative effects on the renal EGFR with STZ-induced diabetic rats (Fig. 2C). PDGF is a coagulation factor that provides proliferation and transformation of cells, regulates apoptosis and is released by many different cells such as fibroblasts, chondrocytes, and glia cells during tissue regeneration. There was a marked functional up-regulation of PDGF in the kidney of rats with diabetes. Resveratrol supplementation significantly suppressed the expression of PDGF (Fig. 2D). Expression of S100B which involves cell proliferation, protein phosphorylation, differentiation, inflammation, and apoptosis, was also apparently enhanced by diabetes. Resveratrol supplementation reduced renal $\mathrm{S} 100 \mathrm{~B}$ in the diabetic rats (Fig. 2E). Nitrite/nitrate levels were lower in the kidney samples of diabetic rats compared with rats in the control groups. Resveratrol supplementation significantly increased nitrite/nitrate levels in the kidneys of the diabetic rats from resveratrol administration during the onset of diabetes (Fig. 2F). The other results show the suppression of renal SOD and CAT activities in the STZ-induced rats (Fig. 2G, $2 \mathrm{H})$. However, treatments with resveratrol did not alter CAT activities but significantly increased $\mathrm{Cu} / \mathrm{Zn}$ SOD activities. As shown in figures $2 \mathrm{G}$ and $2 \mathrm{H}$, supplementation with resveratrol to the healthy rats increased both $\mathrm{Cu} / \mathrm{Zn} \mathrm{SOD}$ and CAT activities in the kidney.

Table 1. Effects of diabetes and resveratrol on body weight and other metabolic parameters in the kidney tissues of STZ-induced diabetic rats.

\begin{tabular}{|c|c|c|c|c|}
\hline 参 & \begin{tabular}{|l} 
Initial \\
body \\
weight \\
(g)
\end{tabular} & $\begin{array}{c}\text { Glucose } \\
\text { (mg/g } \\
\text { protein) }\end{array}$ & $\begin{array}{l}\text { Triglyceride } \\
\text { (mg/g } \\
\text { protein) }\end{array}$ & $\begin{array}{c}\text { Total } \\
\text { Cholesterol } \\
\text { (mg/g protein) }\end{array}$ \\
\hline 宊 & $439 \pm 2$ & $91.6 \pm 7.1$ & $265.3 \pm 2.4$ & $11.4 \pm 2.2$ \\
\hline$\stackrel{\mathscr{z}}{\approx}$ & $401 \pm 6$ & $92.7 \pm 2.2$ & $257.5 \pm 2.6$ & $11.8 \pm 3.1$ \\
\hline 解 & $390 \pm 13^{*}$ & $134.3 \pm 12.5^{*}$ & $383.2 \pm 1.2^{*}$ & $22.1 \pm 3.1 *$ \\
\hline 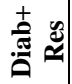 & $397 \pm 5.1$ & $95.8 \pm 9.4 \#$ & $256 \pm 3.7 \#$ & $11 \pm 1.2 \#$ \\
\hline
\end{tabular}

Values are expressed as means \pm SEM, $n=6-12$. Glucose, triglyceride, and total cholesterol levels in the kidney tissues of control, resveratrol (Res), diabetes (Diab), and diabetes plus resveratrol (Diab+Res) groups. Each bar represents at least six rats. $* \mathrm{p}<0.05$, significantly different from control; \# $\mathrm{p}<0.05$, significantly different from Diab.
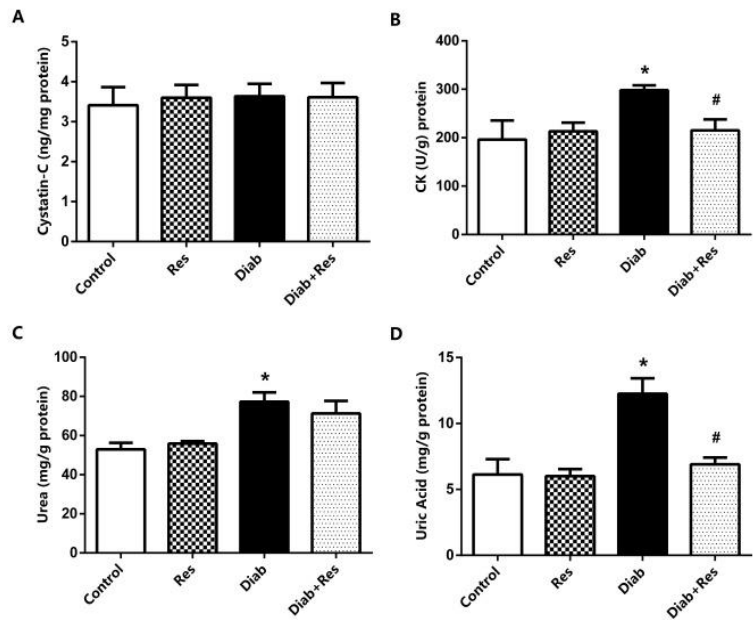

Figure 1. The levels of cystatin-C (A), CK (B), Urea (C), and Uric acid (D) in the kidney tissues of control, resveratrol (Res), diabetes (Diab), and diabetes plus resveratrol (Diab+Res) groups. Values are expressed as means \pm SEM, each bar represents at least six rats. $* \mathrm{p}<0.05$, significantly different from control; \# $\mathrm{p}$ $<0.05$, significantly different from Diab.
A

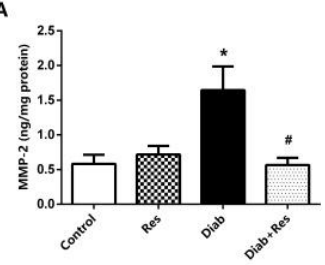

C
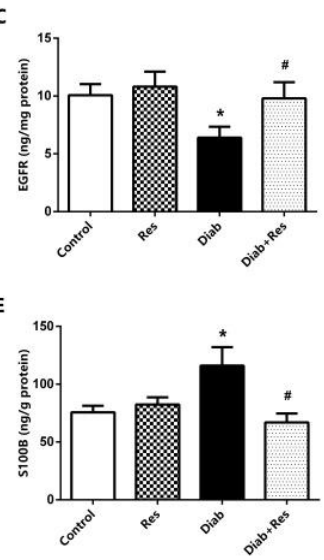

G

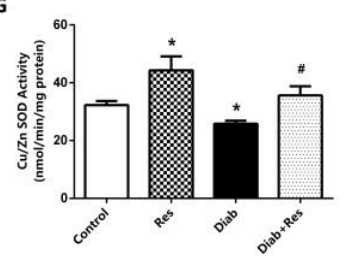

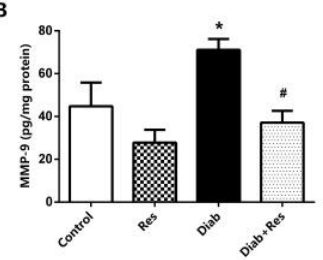

D

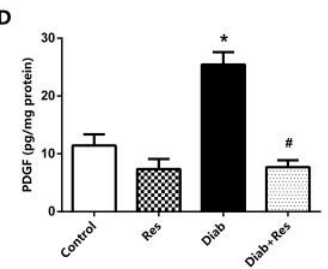

$\mathbf{F}$
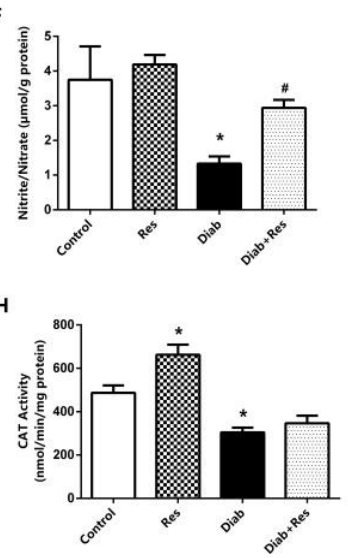

Figure 2. The levels of MMP-2 (A), MMP-9 (B), EGFR (C), PDGF (D), S100B (E), Nitrite/Nitrate (F), SOD (G), and CAT (H) activity in the kidney tissues of control, resveratrol (Res), diabetes (Diab), and diabetes plus resveratrol (Diab+Res) groups. Values are expressed as means \pm SEM, each bar represents at least six rats. $* \mathrm{p}<0.05$, significantly different from control; \# $\mathrm{p}$ $<0.05$, significantly different from Diab.

\section{Discussions}

In this study, we aimed to investigate the effects of resveratrol administration on the relationship between 
MMPs/EGFR and oxidative stress in kidney tissues of rats with STZ-induced diabetes. It is well known that diabetes causes insulin resistance or reduces insulin secretion and accordingly leads to hyperglycemia and hyperlipidemia (Joshua, 2014). It has also been shown several times that bodyweight decreases, especially in type I diabetes models (Akar, 2011; Sadi, 2015). Furthermore, some similar studies showed that tissue glucose, triglyceride, and cholesterol levels increased with type I STZ-induced diabetes model (Pektas, 2016b; Koca, 2016). However, resveratrol supplementations have been shown to reverse these changes (Akar, 2011; Sadi, 2015; Pektas, 2016b; Koca, 2016). In studies performed to date, the hypoglycemic and anti-hyperlipidemic properties of resveratrol were known (Alice, 2018). This study indicated a significant reduction in body weights and also increment of renal glucose, triglyceride, total cholesterol contents with diabetes. Therewithal, resveratrol suppressed renal glucose, triglyceride, and total cholesterol contents in the STZ-induced diabetic rats. In acute or chronic kidney damage that develops with experimental diabetes models created in animals; It has been shown that plasma creatinine, CK, albumin, cystatinC, urea and uric acid levels increase. (Yuko, 2013; Korkmaz, 2019; Safrida, 2019). In this study, a significant increase showed in the levels of renal CK, urea, and uric acid. This could be as a reflection of a diabetes-induced renal disorder. Besides, the fact that unchanged cystatin-C levels may be an indication that the severity is lower of kidney damage. On the other hand, resveratrol application significantly restored CK and uric acid levels.

It has previously been shown that resveratrol can protect against uric acid-induced damage and dysfunction by improving glycemic level (Bhatt, 2012), and it has also been shown to protect pancreatic $\beta$ cells by lowering blood glucose levels in animals with hyperglycemia (Miki, 2011). It has been assigned that resveratrol recovered CK, and $\mathrm{Na}^{+}, \mathrm{K}^{+}$-ATPase activities and its free form, respectively. The correction of these abnormalities by resveratrol supplementation could be valuable in the prevention of the disease. Another unfavorable alter triggered by diabetes is the increase of oxidative stress. Numerous studies demonstrated that increased oxidative end products such as malondialdehyde (MDA) in tissues of rats with diabetes (Pektas, 2016b; Koca, 2016) whereas reduced antioxidant enzyme activities such as SOD, CAT, glutathione (GSH), and glutathione peroxidase (GPx) (Sadi, 2018; Korkmaz, 2019). However, nitrite/nitrate, which is the end-products of nitric oxide known as tissueprotective, has been found to decrease with diabetes (Akar, 2011). In this study, diabetes-induced renal damage was associated with decreased nitrite/nitrate levels and activities of SOD and CAT in the kidney of rats. Prolonged hyperglycemic and hyperlipidemic medium may reflect an inadequacy in the antioxidant defense system in the diabetic condition. Moreover, resveratrol supplementation up-regulated considerably nitrite/nitrate levels and SOD activity withal there was a tendency toward augmentation of CAT activity but the differences did not achieve a significance level. Resveratrol is a potent antioxidant agent that affects endothelial nitric oxide synthase enzyme and mediates to produce nitric oxide which is in accordance with previous results found in type 2 diabetic mice or obese mice (Akar, 2011; Pektas, 2017, 2018; Sadi, 2018). Collectively, these data suggest that resveratrol treatment may improve renal nitric oxide bioavailability and antioxidant capacity.

MMPs family is known to cause chronic kidney disease, and kidney fibrosis present a failed wound healing in progressive chronic kidney disease (Klein, 2004). MMP-2 and MMP-9 are known to encourage cancer cell growth, including the metastasis of cancer cells (Deng, 2017) and has been shown to be profibrotic by induction of renal tubular cell epithelial-mesenchymal transition (Zhu, 2012). In the clinical studies demonstrated that serum MMP-2 and MMP-9 were higher levels in patients with type II Diabetes Mellitus (Signorelli, 2005; Derosa, 2007; Kostov, 2020). Hyperglycemia directly or indirectly (via oxidative stress or advanced glycation products) increases MMPs expression and activity (Kadoglou, 2005). The dysregulation of MMPs activity has been implicated in the pathophysiology of several diabetic co-morbidities (Thrailkill, 2009). As to our findings that MMP-2 and MMP-9 levels were significantly higher in the kidney tissues of rats with diabetes. Conveniently, we can say that results of this study are compatible compared to similar studies. Recently, a study in mice showed that resveratrol inhibits MMP3 and MMP9 expression and secretion by suppressing TLR4/NF-кB/STAT3 activation (Zhang, 2019). Furthermore an improved outcome was be caused by resveratrol-induced reduction in plasma levels of both MMP-2 and MMP-9, as a positive correlation was observed between reductions in both MMPs and patient NIH stroke scales (Chen, 2016). In our findings demonstrated that resveratrol decreased renal MMP-2 and MMP-9 which were raised with diabetes. This could be thought to resveratrol suppress MMPs with its antiinflammatory activity. Previously, it has been shown that down-regulated EGF via progressive renal damage in the kidney of Zucker diabetic fatty (ZDF) rats (Togashi, 2013). Similarly, Wu et al. (2019) demonstrated that EGFR levels significantly reduced in the heart tissues of STZ-induced type I diabetic mice (Wu, 2019). Here in, our findings denoted to support existing results that renal EGFR levels significantly reduced with diabetes. On the other hand, resveratrol normalized the levels of EGFR in the kidney of diabetic rats. In a similar study, resveratrol has been shown to an increase in EGFR expressions in liver tissues of diet-induced obese mice (Jin, 2019). It is possible to say that in diabetes-induced kidney damage, resveratrol shows restorative effectiveness by increasing EGFR levels. Howbeit, in our study, some of the evidence of diabetes-induced renal damage is the increase of renal S100B and PDGF levels. It can be assumed that they were secreted from infiltrating inflammatory cells and platelets for recovery of prolonged hyperglycemia medium-induced kidney damage (Abderrahmani, 2018; Katsanou, 2018; Mohammadzadeh, 2018; Shan, 2019; Yu, 2020).

In conclusion, resveratrol alleviates type 1 diabetesinduced renal damage by decreasing renal oxidative stress and stabilizing MMPs/EGFR thereby increasing the reconstructions of the kidney. Although resveratrol treatment did not shift the overall diabetic pattern toward control conditions, it significantly protected renal functions and integrity from the diabetes-induced kidney damage.

Conflict of interest: The authors state no conflict of interest. 
Acknowledgements: This study has not been supported by any institution or organization.

Abbreviations: CAT, catalase; CK, creatine kinase; Diab, diabetes; EGFR, epidermal growth factor receptor; ERK, extracellular signal-regulated kinase; GPx, glutathione peroxidase; GSH, glutathione; MDA, malondialdehyde;
MMPs, Matrix metalloproteinases; NfkB, nuclear factor kappa B; NIH, national institutes of health. PDGF, platelet-derived growth factor; Res, resveratrol; SOD, superoxide dismutase; STAT3, signal transducer and activator of transcription 3; STZ, streptozotocin; S100B, calcium-binding protein B; TLR4, toll like receptor 4 .

\section{References}

Abdelgawad IY, Grant MKO, Zordoky BN (2019). Leveraging the cardio-protective and anticancer properties of resveratrol in cardio-oncology. Nutrients 11(3): 627.

Abderrahmani A, Yengo L, Caiazzo R, Canouil M, Cauchi S, Raverdy V, Plaisance V, Pawlowski V, Lobbens S, Maillet J, et al (2018). Increased hepatic PDGF-AA signaling mediates liver insulin resistance in obesity-associated type 2 diabetes. Diabetes 67(7): 1310-1321.

Adlija JC, Maja M, Tanja D (2006). Creatine kinase activity in patients with diabetes mellitus type I and type II. Bosnian Journal of Basic Medical Sciences 6(3): 5-9.

Akar F, Pektas MB, Tufan C, Soylemez S, Sepici A, Ulus AT, Gokalp B, Ozturk K, Surucu HS (2011). Resveratrol shows vasoprotective effect reducing oxidative stress without affecting metabolic disturbances in insulin dependent diabetes of rabbits. Cardiovascular Drugs and Therapy 25(2): 119-131.

Alice C, Christian C, Josep M (2018). Resveratrol, metabolic syndrome, and gut microbiota. Nutrients 10(11): 1651.

Ankita S, Lokesh K, Thomas PJ, Kedar SP (2019). Targeting matrix metalloproteinases for diabetic retinopathy: The way ahead? Current Protein \& Peptide Science 20(4): 324-333.

Babacanoglu C, Yildirim N, Sadi G, Pektas MB, Akar F (2013). Resveratrol prevents high-fructose corn syrup induced vascular insulin resistance and dysfunction in rats. Food and Chemical Toxicology 60: 160-167.

Bhatt JK, Thomas S, Nanjan MJ (2012). Resveratrol supplementation improves glycemic control in type 2 diabetes mellitus. Nutrition Research 32(7): 537-541.

Chen J, Bai Q, Zhao Z, Sui H, Xie X (2016). Resveratrol improves delayed r-tPA treatment outcome by reducing MMPs. Acta Neurologica Scandinavica 134(1): 54-60.

Deng R, Mo F, Chang B, Zhang Q, Ran H, Yang S, Zhu Z, Hu L, Su Q (2017). Glucose-derived AGEs enhance human gastric cancer metastasis through RAGE/ERK/Sp1/MMP2 cascade. Oncotarget 8(61): 104216-104226.

Derosa G, D'angelo A, Tinelli C, Devangelio E, Consoli A, Miccoli R, Penno G, Del Prato S, Paniga S, Cicero AFG (2007). Evaluation of metalloproteinase 2 and 9 levels and their inhibitors in diabetic and healthy subjects. Diabetes \& Metabolism 33: 129-134.

Guglielmo S, Francesca R, Cataldo A, Claudia T, Roberta B, Ileana G, Rosario D (2013). S100B protein in tissue development, repair and regeneration. World Journal of Biological Chemistry 4(1): 1-12.

Jenifer K, Janaína K, Itiane F, Vivian N, Matheus DB, Cláudia GP, Nathana JM, Guilherme C, Luciane RF, Liana SF, et al (2019). Resveratrol and resveratrol-hydroxypropyl- $\beta$ - cyclodextrin complex recovered the changes of creatine kinase and $\mathrm{Na}+\mathrm{K}+$-ATPase activities found in the spleen from streptozotocin-induced diabetic rats. Anais da Academia Brasileira de Ciências 91(3): e20181330.

Jin X, Zimmers TA, Zhang Z, Koniaris LG (2019). Resveratrol improves recovery and survival of diet-induced obese mice undergoing extended major (80\%) hepatectomy. Digestive Diseases and Sciences 64(1): 93-101.

Joshua JJ, Sherita HG (2014). Type 2 diabetes and cardiovascular disease: what next? Current Opinion in Endocrinology Diabetes and Obesity 21(2): 109-120.

Kadoglou NP, Daskalopoulou SS, Perrea D, Liapis CD (2005). Matrix metalloproteinases and diabetic vascular complications, Angiology 56(2): 173-189.

Katsanou P, Tentolouris N, Perrea D, Katsanos S, Ntova V, Antrian V, Konstantopoulos P, Politis A (2018). S100B levels in patients with type 2 diabetes mellitus and co-occurring depressive symptoms. Depression Research and Treatment 2018: 5304759.

Klein G, Vellenga E, Fraaije MW, Kampsa WA, de Bont ESJM (2004). The possible role of matrix metalloproteinase (MMP)-2 and MMP-9 in cancer, e.g. acute leukemia. Critical Reviews in Oncology/Hematology 50: 87-100.

Koca HB, Pektas MB, Koca S, Pektas G, Sadi G (2016). Diabetes-induced renal failure is associated with tissue inflammation and neutrophil gelatinase-associated lipocalin: Effects of resveratrol. Archives of Biological Sciences 68(4): 747-752.

Korkmaz OA, Sadi G, Kocabas A, Yildirim OG, Sumlu E, Koca HB, Nalbantoglu B, Pektas MB, Akar F (2019). Lactobacillus helveticus and Lactobacillus plantarum modulate renal antioxidant status in a rat model of fructose-induced metabolic syndrome. Archives of Biological Sciences 5: 1-8.

Kostov K, Blazhev A (2020). Use of glycated hemoglobin (A1c) as a biomarker for vascular risk in type 2 diabetes: Its relationship with matrix metalloproteinases-2, -9 and the metabolism of collagen IV and elastin. Medicina 56(5): 231.

Lowry OH, Rosebrough NJ, Farr AL, Randall RJ (1951). Protein measurement with the Folin phenol reagent Journal of Biological Chemistry 193: 265-275.

Mahshad K, Fardin A, Ashraf M, Ladan K, Maryam SN, Azar P, Mojdeh B, Samaneh B, Aligholi S (2019). The modulating 
effects of Resveratrol on the expression of MMP-2 and MMP-9 in endometriosis women: a randomized exploratory trial. Gynecological Endocrinology 35(8): 719-726.

Melenhorst WB, Mulder GM, Xi Q, Joost GJ, Kimura K, Eguchi S, Goor H (2008). Epidermal growth factor receptor signaling in the kidney: key roles in physiology and disease. Hypertension 52(6): 987-993.

Miki M, Atutoshi K, Yutaka M, Kazumi Y (2011). Hypoglycemic effect of resveratrol in type 2 diabetic model db/db mice and its actions in cultured L6 myotubes and RIN-5F pancreatic $\beta$-cells. Journal of Clinical Biochemistry and Nutrition 48(3): 237-244.

Mohammadzadeh F, Tsoporis JN, Izhar S, Desjardins JF, Parker TG (2018). Deficiency of S100B confers resistance to experimental diabetes in mice. Experimental Cell Research 365(1): 129-137.

Naseer AS, Muhammad RK (2014). Antidiabetic effect of Sida cordata in alloxan induced diabetic rats. BioMed Research International 2014: 671294.

Ning C, Min H, Raouf AK (2017). Biochemical and biological attributes of matrix metalloproteinases. Progress in Molecular Biology and Translational Science 147: 1-73.

Pektas A, Sadi G, Pektas MB, Koca HB, Tosun M, Aslan E, Koca S (2017). Effects of resveratrol on diabetes induced vascular tissue damage and inflammation in male rats. Turkish Journal of Biochemistry 42(4): 451-458.

Pektas MB, Sadi G, Akar F (2015). Long-term dietary fructose causes gender-different metabolic and vascular dysfunction in rats: modulatory effects of resveratrol. Cellular Physiology and Biochemistry 37: 1407-1420.

Pektas MB, Sadi G, Koca HB, Yuksel Y, Vurmaz A, Koca T, Tosun M (2016a). Resveratrol ameliorates the components of hepatic inflammation and apoptosis in a rat model of streptozotocin-induced diabetes. Drug Development 77(1): 12-19.

Pektas MB, Koca HB, Sadi G, Akar F (2016b). Dietary fructose activates insulin signaling and inflammation in adipose tissue: Modulatory role of resveratrol. BioMed Research International 2016: 8014252.

Pektas MB, Yücel G, Koca HB, Sadi G, Yıldırım OG, Öztürk G, Akar F (2017). Dietary fructose-induced hepatic injury in male and female rats: Influence of resveratrol. Drug Research 67(2): 103-110.

Pektas MB, Turan O, Ozturk-Bingol G, Sumlu E, Sadi G, Akar F (2018). High glucose causes vascular dysfunction through Akt/eNOS pathway: reciprocal modulation by juglone and resveratrol. Canadian Journal of Biochemistry and Physiology. 96(8): 757-764.

Qian S, Zi-Ying S, Wei-Na D, Qing-Tao M, Zhong-Yuan X (2017). Mechanism of myocardial ischemia / reperfusion-induced acute kidney injury through DJ-1/Nrf2 pathway in diabetic rats. Experimental and Therapeutic Medicine 14(5): 42014207.

Renu AK, Manish M (2017). Regulation of matrix metalloproteinase in the pathogenesis of diabetic retinopathy. Progress in Molecular Biology and Translational Science 148: 67-85.

Sadi G, Baloglu MC, Pektas MB (2015). Differential gene expression in liver tissues of streptozotocin-induced diabetic rats in response to resveratrol treatment. PLoS One 2015; 10(4): e0124968.

Sadi G, Pektas MB, Koca HB, Tosun M, Koca T (2015). Resveratrol improves hepatic insulin signaling and reduces the inflammatory response in streptozotocin induced diabetes. Gene; 570(2): 213-220.

Sadi G, Şahin G, Bostanc1 A (2018). Modulation of renal insulin signaling pathway and antioxidant enzymes with streptozotocininduced diabetes: Effects of resveratrol. Medicina; 55(3): 1-12.

Safrida S, Sabri M (2019). Effect of Muntingia calabura L. stem bark extracts on uric acid concentration and renal histopathology in diabetic rats. Medicina 55(10): 695.

Shan Z, Xu C, Wang W, Li W (2019). Enhanced PDGF signaling in gestational diabetes mellitus is involved in pancreatic $\beta$-cell dysfunction. Biochemical and Biophysical Research Communications 516(2): 402-407.

Signorelli SS, Malaponte G, Libra M, Di Pino L, Celotta G, Bevelacqua V, Petrina M, Nicotra GS, Indelicato M, Navolanic PM and et al (2005). Plasma levels and zymographic activities of matrix metalloproteinases 2 and 9 in type II diabetics with peripheral arterial disease. Vascular Medicine 10(1): 1-6.

Sigrun G, Simon F, Alexandra A, Minoru T, Erika G, Reinhard F, Christer B (2004). Endothelium-specific ablation of PDGFB leads to pericyte loss and glomerular, cardiac and placental abnormalities. Development 131(8): 1847-1857.

Sreyashi M, Sayantan B, Sudipta R, Rinku S, Paramita G, Sanchita R, Syamsundar M, Samir B, Nabendu M (2016). Resveratrol alleviates cadmium-induced damage and overexpression of epidermal growth factor receptor and its downstream signaling proteins in the reproductive system of male Swiss albino mice. The Journal of Environmental Pathology, Toxicology, and Oncology 35(1): 73-90.

Taizo N, Hiroshi I, Masakiyo S (2012). Platelet-derived growth factor and renal disease. Current Opinion in Nephrology and Hypertension 21(1): 80- 85.

Talib AH, Thazhumpal CM, Ali AD, Sami A, Al-Zaid N, Hussein MD (2012). Effect of low-calorie versus low-carbohydrate ketogenic diet in type 2 diabetes. Nutrition 28(10): 1016-1021.

Thrailkill KM, Bunn C, Fowlkes JL (2009). Matrix metalloproteinases: their potential role in the pathogenesis of diabetic nephropathy. Endocrine 35(1): 1-10.

Togashi Y, Miyamoto Y (2013). Urinary cystatin C as a biomarker for diabetic nephropathy and its immunohistochemical localization in kidney in Zucker diabetic fatty (ZDF) rats. Experimental and Toxicologic Pathology 65(5): 615-622.

Wu L, Lan H, Jingying W, Fei Z, Zheng X, Haimin Y, Yuanyuan Q, Guang L, Chao Z, Yi W (2019). Inhibition of EGFR-STAT3 
attenuates cardiomyopathy in streptozotocin-induced type 1 diabetes. Journal of Endocrinology 242(3): 199-210.

Xue-Wen L, Hui-Ping C, Ying-Yan H, Wei-Li C, Jian-Wen C, Lu G, Hai-Yan H, Jun W (2018). Effects of rich-polyphenols extract of Dendrobium loddigesii on anti-diabetic, anti-inflammatory, anti-oxidant, and gut microbiota modulation in $\mathrm{db} / \mathrm{db}$ mice. Molecules 23(12): 3245 .

Yoshioka K, Takemura T, Murakami K, Akano N, Matsubara K, Aya N, Maki S (1990). Identification and localization of epidermal growth factor and its receptor in the human glomerulus. Laboratory Investigation 63(2): 189-196.

Yu H, Li H, Liu X, Du X, Deng B (2020). Levels of serum S100B are associated with cognitive dysfunction in patients with type 2 diabetes Aging 2020 12(5): 4193-4203.

Yuko T, Yohei M (2013). Urinary cystatin C as a biomarker for diabetic nephropathy and its immunohistochemical localization in kidney in Zucker diabetic fatty (ZDF) rats. Experimental and Toxicologic Pathology 65(5): 615-622.

Zeng-Mei A, Xing-Gang D, Yuan G, Jia-Liang Z, Tao Q (2015). Effects and clinical significance of pentoxifylline on the oxidative stress of rats with diabetic nephropathy. Huazhong University of Science and Technology Medical Sciences 35(3): 356-661.

Zhang M, Xue Y, Chen H, Meng L, Chen B, Gong H, Zhao Y, Qi R (2019). Resveratrol inhibits MMP3 and MMP9 expression and secretion by suppressing TLR4/NF- $\kappa$ B/STAT3 activation in Ox-LDL-treated HUVECs oxid Oxidative Medicine and Cellular Longevity 2019: 9013169.

Zhu P, Ren M, Yang C, Hu YX, Ran JM, Yan L (2012). Involvement of RAGE, MAPK and NF- $\mathrm{BB}$ pathways in AGEs-induced MMP-9 activation in HaCaT keratinocytes. Experimental Dermatology 21: 123-129. 